\title{
A Systematic Review of Artificial Intelligence Applications in Cellular Networks
}

\author{
Ngozi Clara Eli-Chukwu \\ Department of Electrical \& Electronics \\ Engineering, Alex Ekwueme Federal \\ University, Ndufu Alike, Ebonyi, Nigeria \\ ngozieli@gmail.com
}

\author{
J. M. Aloh \\ Department of Electrical \& Electronics \\ Engineering, Alex Ekwueme Federal \\ University, Ndufu Alike, Ebonyi, Nigeria \\ joedreams4u@yahoo.com
}

\author{
Christopher Ogwugwuam Ezeagwu \\ Department of Electrical \& Electronics \\ Engineering, Nnamdi Azikiwe \\ University, Awka, Nigeria \\ ogwugwuamezeagwu@gmail.com
}

\begin{abstract}
Mobile technology has made communication easier and faster. People communicate in a matter of picoseconds, with little or no inhibition, regardless of their distance or location. Mobile networks are rapidly expanding all over the world. The demand led to the evolution of different technologies to meet with traffic challenges. Challenges are still evident as the cellular network system faces dynamic and chaotic behavior that needs to be resolved intelligently without human intervention. The current paper presents the state of the art of artificial intelligence (AI) in enhancing the performance of cellular networks. This paper summarizes the AI concept and reviews its applications in cellular network design, operations, and optimization. A special focus is laid on the advantages and disadvantages of AI application and a holistic study of the challenges is undertaken in order to give new research directions.
\end{abstract}

Keywords-artificial intelligence; cellular network; network design; operations; optimization; network management

\section{INTRODUCTION}

The telecommunication industry is witnessing an explosion as the demand for its services and applications is geometrically increasing. Facing the challenges associated with this tremendous rise led to the evolution of different technologies: second generation, third generation, fourth generation and the future fifth generation networks and beyond. The $3 \mathrm{G}$ supports high data rates of about $14.0 \mathrm{Mbps}$ and $5.8 \mathrm{Mbps}$ for downlink and uplink respectively while the $4 \mathrm{G}$ has an estimated peak rate of about 100Mbps [1]. The massive increase in the usage of devices and communication between machines which are internet dependant is expected to put pressure on the recent $4 \mathrm{G}$ technology. It is envisaged that there will be over a thousand times increase in network traffic because of the increaesd demand [2]. To tackle this in future networks, the system and network drivers need to get smarter and more automated. System automation in a radio network is realizable through AI [2]. The AI can be applied in different layers of cellular network architecture: antenna design, network management, vendor-operator service level of agreement, etc.

\section{THE NEED FOR AI IN A CELLULAR NETWORK}

$\mathrm{AI}$ is an autonomous system with the capacity to learn, reason, take decisions and solve problems [3]. It is a system with the capacity to act relatively like a human $[4,5]$. The Corresponding author: Ngozi Clara Eli-Chukwu artificial in the intelligence is derived from the fact that the autonomous system is not human, but human will design, train the system (in a supervised and/or unsupervised manner) to think, reason and take decisions in solving real-world problems. Its action is beyond the input/output of a computer system. In an artificially intelligent system, the human mind is mimicked by the system that learns the environment and solves the problem [2]. An AI system has the capacity to identify, predict, and execute tasks [6]. The acquired data can be studied over time and used in predicting future network behavior while they are also deployed in resolving network challenges [6]. To enhance the performance of a cellular network, the overall life cycle of cellular network planning, design, operation, implementation, and maintenance need to be embedded in the AI system, starting from network planning [7]. In this study, four intelligent agent tools were considered: Artificial Neural Networks (ANN), Fuzzy Network (FN), Re-enforced Learning and Case-Based Reasoning (CBR).

\section{AI IN CELLULAR NETWORK DESIGN}

The performance of a cellular network system depends on system design. Cellular network designs consider various parameters that measure overall network performance. As the cellular and PC worlds collide with wireless LANs and internet-based packet data, new networking approaches will support the integration of voice and data on the composite infrastructure of cellular base stations (BSs) and Ethernet-based wireless access points [8]. When designing a cellular network that will carry a multitude of traffic, it is essential to consider different parameters and/or different requirements, such as different mobility parameters or quality-of-service requirements. In such situations, it may be cost-effective to build many cellular infrastructures, each serving a particular traffic type. The network resources (e.g. radio channels) are then divided [9]. Authors in [10] proposed a design that improves only cellular network dependability using neural networks. This research uses simulations to train and validate the neural network. A wide range of traffic scenarios were studied and sensitivity analysis was performed to determine a reliable solution to improve availability, reliability, maintainability, and survivability of the network. Authors in [11] proposed designing a system that considers Radio Resource Management (RRM) parameters using fuzzy logic 
controllers to improve cellular network performance. The proposed design uses fuzzy logic controllers to improve network call admission. The drawback of the proposed design is that it does not improve cellular service retainability. Authors in [12] proposed an appropriate model for cooperative and cross-layer design that uses cognitive radio and multi-hop network to reduce extended mobility management challenges. Although the proposed cross-layer design improved network service retainability, it fell short in service availability, accessibility, and integrity. Authors in [13] proposed a cellular network system that considers handover as a parameter for improving network performance using fuzzy controlling [13]. Authors in [14] used Cell Individual Offset (CIO) to manage a handover algorithm that increases the network capacity by $9 \%$. They also proposed admission control for WCDMA/WLAN heterogeneous network with multimedia traffic. The proposed design uses the Fuzzy Q-learning Admission Control (FQAC) system managed by the minimax theorem to estimate call admission request time. The FQAC design achieved lower blocking probabilities and reduced handoff rate by $20 \%$.

Authors in [15] proposed a hybrid cognitive engine for improving coverage in a $3 \mathrm{G}$ wireless network. The proposed hybrid system uses case-based reasoning and decision tree algorithm to learn the coverage of a cell, predicts if handover is necessary and determines policy patterns to improve $3 \mathrm{G}$ network coverage. Authors in [16] proposed a vertical handover decision algorithm in $4 \mathrm{G}$ heterogeneous wireless networks. Although the Vertical Handover Decision (VHD) algorithm allows seamless roaming of network technologies, it does not impact service accessibility. In [17], authors provided an efficient radio access technology selection for the next generation wireless networks. Their proposed system uses fuzzy logic controllers, Genetic Algorithm (GA), particle swarm optimization and multi-criteria decision-making methods for radio access decision making. The algorithm performs better than the radio resource management algorithm and provides highest user satisfaction. Authors in [18] proposed an artificial neural network algorithm that reduces handoff latency. The proposed algorithm combines multiple attribute decision making and artificial neural network to determine if a handoff is a necessary by comparing the values of the devices' bit rate, cost of transmitting specified data bytes and the RSSI. The neural network based algorithm significantly reduces handoff latency. Authors in [19] proposed a CAC scheme for multimedia applications based on fuzzy logic. The proposed scheme is called fuzzy admission control for multimedia applications (MFAC). The design comprises of fuzzy QoS controller (FQC) and fuzzy congestion controller (FCC). MFAC improved the call admission rate by reducing system congestion.

Designing a system that improves integral channel allocation algorithms in cellular communication systems enabling multimedia QoS services was proposed in [20]. The proposed design used dynamic channel assignment algorithms to provide the requested capacity for the preferred service, supported data and video (video viewing, video conference) transmission with Quality of Service (QoS) by reducing signal interference reported by the CNR and CNIR. This design will fail in network accessibility as it was not considered. Authors in [21] proposed an intelligent agent that uses case-based reasoning to control radio resource allocation and congestion control. In [21], a congestion pattern in WCDMA was extensively studied and embedded in a CBR with their respective solutions, such that when the system anticipates congestion, the CBR searches the case library to get a matching solution. Recently, authors in [22] saw system fault as a major draw-back in effective QoS delivery and they proposed a design that uses fuzzy reasoning in communication network fault diagnosis. The proposed design processes network alarms into fuzzy network alarm that is compatible with fuzzy reasoning. In this way, the root alarm can be located more quickly and accurately. More recently, authors in [23] studied the use of AI to perform handoff in cellular network design when they proposed an intelligent handoff algorithm to enhance the quality of service in high altitude platforms using neural networks. The research design combines high altitude platforms and terrestrial system in a handoff algorithm to improve signal coverage in a cellular network. It was found that hand-off rate and blocking rate are greatly improved using ANNs for handoff decision.

Authors in [24] proposed a secure-aware call admission control scheme for wireless cellular networks using fuzzy logic. The proposed secure-aware CAC scheme uses fuzzy logic to improve call admission rate. Elastic call admission control using fuzzy logic in virtualized cloud radio base stations was proposed in [25]. The proposed design uses fuzzy logic in C-RAN to run an intelligent elastic CAC scheme. In this scheme, the BS resources are consolidated to the cloud by using virtualization technology and dynamically provisioned using the elasticity concept of cloud computing in accordance with traffic demands. Simulations showed that the proposed CAC algorithm has high call acceptance rate compared to conventional CAC. Authors in [26] proposed a new hybrid prediction model that optimizes handoff delay and predicts the next location of the mobile station. The proposed architecture uses a GPS integrated SIM for MS location and a prediction server embedded in the BSC to assign the mobile station to a non-congested BS amongst the BTSs under its control. The design focuses on service accessibility. Service retainability and integrity are major drawbacks of the design. Table I summarizes the above mentioned techniques and implementations with their advantages and disadvantages.

\section{AI IN CELLULAR NETWORK OPERATIONS}

In WCDMA, the traffic exhibits high fluctuations in time and over space, thus incurring energy waste [27]. During crowded events, cellular networks face voice and data traffic volumes that are often orders of magnitude higher than what they face during routine days. Despite the use of portable BSs for temporarily increasing communication capacity and free Wi-Fi access points for offloading internet traffic from cellular base stations, crowded events still present significant challenges for cellular network operators looking to reduce dropped call events and improve internet speeds [28]. Designing an intelligent agent to manage the operations of a cellular network will improve the overall quality of service. Authors in [29] proposed a mobility management design that incorporates fuzzy logic for a heterogeneous IP environment. 
TABLE I. AI IN CELLULAR NETWORKS DESIGN

\begin{tabular}{|c|c|c|c|}
\hline Reference & AI technique & Advantages & Disadvantages \\
\hline$[10]$ & ANN & $\begin{array}{c}\text { Network availability, } \\
\text { reliability, } \\
\text { maintainability, and } \\
\text { survivability. }\end{array}$ & $\begin{array}{l}\text { Accessibility and } \\
\text { retainability were not } \\
\text { considered. }\end{array}$ \\
\hline [11] & $\begin{array}{c}\text { Fuzzy Logic } \\
\text { Controller (FLC) }\end{array}$ & $\begin{array}{l}\text { Improved service } \\
\text { admission control. }\end{array}$ & $\begin{array}{l}\text { No improvement in } \\
\text { traffic capacity. Traffic } \\
\text { retainability was not } \\
\text { considered. }\end{array}$ \\
\hline [12] & $\begin{array}{c}\text { Cognitive Radio } \\
\text { (CR) }\end{array}$ & $\begin{array}{c}\text { Satisfactory } \\
\text { performance in } \\
\text { mobility management }\end{array}$ & $\begin{array}{c}\text { Availability, } \\
\text { accessibility, integrity } \\
\text { and retainability were } \\
\text { not considered }\end{array}$ \\
\hline$[13]$ & FLC & $\begin{array}{c}\text { Improved the network } \\
\text { capacity by } 9 \% .\end{array}$ & $\begin{array}{c}\text { It only solves current } \\
\text { capacity problems and } \\
\text { cannot be deployed } \\
\text { when } \\
\text { there is additional } \\
\text { network load. }\end{array}$ \\
\hline [14] & FQAC and NFIS & $\begin{array}{l}\text { Improves and } \\
\text { manages network } \\
\text { accessibility. }\end{array}$ & $\begin{array}{l}\text { Restricted to network } \\
\text { service accessibility. } \\
\text { Some service requests } \\
\text { are still rejected. }\end{array}$ \\
\hline$[15]$ & $\begin{array}{l}\text { CR, Decision } \\
\text { Tree (DT) and } \\
\text { CBR }\end{array}$ & $\begin{array}{l}\text { Improvement in } \\
\text { signal coverage. }\end{array}$ & $\begin{array}{l}\text { Signal quality and } \\
\text { other relevant KPIs } \\
\text { used to assess the } \\
\text { network were not } \\
\text { discussed. }\end{array}$ \\
\hline$[16]$ & VHD & $\begin{array}{l}\text { Allows seamless } \\
\text { roaming of network } \\
\text { technologies. }\end{array}$ & $\begin{array}{l}\text { Only considered } \\
\text { retainability. }\end{array}$ \\
\hline$[17]$ & FLC and GA & $\begin{array}{c}\text { Easy network access } \\
\text { and high user } \\
\text { satistisfaction. }\end{array}$ & $\begin{array}{l}\text { KPIs such as speech } \\
\text { quality and handover } \\
\text { were not studied. }\end{array}$ \\
\hline [18] & $\begin{array}{c}\text { Multiple } \\
\text { Attribute } \\
\text { Decision } \\
\text { Making } \\
\text { Algorithm and } \\
\text { ANN } \\
\end{array}$ & $\begin{array}{l}\text { Manages handoff } \\
\text { number and reduces } \\
\text { handoff latency. }\end{array}$ & $\begin{array}{l}\text { Will surely fail in } \\
\text { availability, } \\
\text { accessibility and } \\
\text { integrity. }\end{array}$ \\
\hline [19] & $\begin{array}{l}\text { MFAC, FQC, } \\
\text { and FCC }\end{array}$ & $\begin{array}{l}\text { Improved call } \\
\text { admission rate by } \\
\text { reducing system } \\
\text { congestion. }\end{array}$ & $\begin{array}{l}\text { QoS and service } \\
\text { retainability were not } \\
\text { considered. }\end{array}$ \\
\hline$[20]$ & $\begin{array}{l}\text { Dynamic } \\
\text { Channel } \\
\text { Assignment } \\
\text { (DCA) }\end{array}$ & $\begin{array}{l}\text { Improved QoS by } \\
\text { reducing interference. }\end{array}$ & $\begin{array}{l}\text { No work was done on } \\
\text { network accessibility. }\end{array}$ \\
\hline [21] & CBR & $\begin{array}{l}\text { Reduces congestion } \\
\text { during cellular } \\
\text { network traffic } \\
\text { session. }\end{array}$ & $\begin{array}{l}\text { Case matching and } \\
\text { learning process are } \\
\text { slow. }\end{array}$ \\
\hline [22] & $\begin{array}{l}\text { Fuzzy } \\
\text { Reasoning } \\
\text { Algorithm }\end{array}$ & $\begin{array}{c}\text { Detects the root cause } \\
\text { of cellular network } \\
\text { alarm quickly and } \\
\text { accurately. }\end{array}$ & $\begin{array}{l}\text { It does not fix the } \\
\text { detected alarm. }\end{array}$ \\
\hline [23] & ANN & $\begin{array}{l}\text { Reduced network } \\
\text { blocking rate }\end{array}$ & $\begin{array}{l}\text { Did not consider QoS. } \\
\text { The blocking } \\
\text { performance is limited } \\
\text { to handoff cases. }\end{array}$ \\
\hline [24] & $\begin{array}{l}\text { Fuzzy Logic } \\
\text { (FL) and } \\
\text { FCACS }\end{array}$ & $\begin{array}{l}\text { Improved call } \\
\text { admission rate. }\end{array}$ & $\begin{array}{l}\text { Limited number of } \\
\text { subscribers. System } \\
\text { capacity was not } \\
\text { consider. }\end{array}$ \\
\hline$[25]$ & FL & $\begin{array}{c}\text { High call acceptance } \\
\text { rate }\end{array}$ & $\begin{array}{l}\text { No considerations for } \\
\text { dropping probabilities. }\end{array}$ \\
\hline$[26]$ & $\begin{array}{l}\text { GPS/SIM } \\
\text { detection } \\
\text { algorithm }\end{array}$ & $\begin{array}{l}\text { Improves service } \\
\text { accessiblity }\end{array}$ & $\begin{array}{l}\text { Service retainability } \\
\text { and integrity. }\end{array}$ \\
\hline
\end{tabular}

The proposed design uses a fuzzy inference method to process a multi-criteria vertical handover decision metrics. A vertical handover decision algorithm to decode a handover is necessary. Although the design recorded improvement in the system mobility it never handled the case of service accessibility. Authors in [30] proposed a GSM mobile station location using reference stations and ANNs based on the measurements of radio signal strength from a number of neighbouring base stations (antennas) and estimation of the mobile station position using trained ANN models. An improved version of the positioning Back-Propagation (BP) ANN multi-level perceptron (MLP) model that improves positioning accuracy and an extension of the MLP primary ANN model by introducing correctional factors were obtained from a number of reference stations. Authors in [27] proposed a traffic-driven power saving in operational $3 \mathrm{G}$ cellular networks. A profile-based approach to green cellular infrastructure was proposed. BS traffic and approximate network-wide energy proportionality were studied using nonload-adaptive base stations. The proposed scheme yields up to $53 \%$ energy saving in a dense large city and $23 \%$ in a sparse, mid-sized city. Authors in [31] proposed an adaptive multicriteria vertical handoff decision algorithm for radio heterogeneous network. The algorithm is made up of the fuzzy interference system that adopts crucial criteria of vertical handoff and the modified Elman NN for predicting the number of users. Although it improves subscribers' mobility, service accessibility remains a problem. A knowledge-based model for analyzing GSM network performance was proposed in [32]. The research analyzed GSM network performance using quadratic programming to estimate GSM parameters. The parameter estimates were used to find the input-output variable pairs involved in the most severe performance degradations. Authors in [33] proposed a case-based reasoning agent for resource management in $3 \mathrm{G}$ networks. The research presented a new method of balancing traffic load in mobile cellular networks by using CBR to learn traffic patterns at periods of congestion. The obtained traffic patterns were then used to control co-operating semi-smart antennas to optimize the radio coverage, hence minimizing the effects of congestion. The scheme is restricted to curbing congestion which is not up to $25 \%$ of $3 \mathrm{G}$ challenges. Authors in [34] proposed performance analysis of call admission control in a WCDMA system with adaptive multi-class Traffic based on FL. The fuzzy CAC scheme considers the mobility information of the new user requesting connection and already existing users, the type of service request (real time or non-real time), and the load factor which is calculated from the intra-cell interference and the inter-cell interference at the base station. The QoS requirement of the non-real time traffic is reduced to accommodate a higher number of real-time traffic users to improve the performance of the admission control scheme. Although the fuzzy based CAC scheme performs better than the fixed CAC schemes without fuzzy in terms of new call blocking and handoff call dropping probabilities, it requires longer time to access the network. Authors in [35] proposed advanced analysis methods for $3 \mathrm{G}$ cellular networks. They presented an algorithm called SelfOrganizing Map (SOM) together with a conventional clustering method for simplified network analysis. 
TABLE II. AI IN CELLULAR NETWORK OPERATION

\begin{tabular}{|c|c|c|c|}
\hline Reference & AI technique & Advantages & Disadvantages \\
\hline [29] & FL & $\begin{array}{c}\text { Handover } \\
\text { management. }\end{array}$ & $\begin{array}{l}\text { Limited KPIs were } \\
\text { discussed. }\end{array}$ \\
\hline$[30]$ & ANN, BP, MLP & $\begin{array}{l}\text { Swift and accurate } \\
\text { reporting of radio } \\
\text { signal strength and } \\
\text { mobile station } \\
\text { location }\end{array}$ & $\begin{array}{c}\text { Takes time to train the } \\
\text { data and no KPI was } \\
\text { discussed. }\end{array}$ \\
\hline [27] & $\begin{array}{l}\text { BS Profile-based } \\
\text { approach }\end{array}$ & $\begin{array}{l}\text { Saved energy up to } \\
53 \% \text { and } 23 \% \text { in } \\
\text { dense-large and } \\
\text { mid-large cities. }\end{array}$ & $\begin{array}{l}\text { Does not discuss } \\
\text { subscribers' interest. }\end{array}$ \\
\hline [28] & $\begin{array}{l}\text { Fuzzy Logic } \\
\text { Quantitative } \\
\text { Decision } \\
\text { Algorithm } \\
\text { (FQDA) }\end{array}$ & $\begin{array}{l}\text { Impoved service } \\
\text { availability and } \\
\text { accessibility. }\end{array}$ & $\begin{array}{l}\text { The rate of service } \\
\text { retainability was not } \\
\text { discussed. }\end{array}$ \\
\hline [31] & $\begin{array}{l}\text { Adaptive Multi- } \\
\text { Criteria Vertical } \\
\text { Handoff } \\
\text { (AMVHO), FIS, } \\
\text { and Modified } \\
\text { Elman NN } \\
\text { (MENN) }\end{array}$ & $\begin{array}{l}\text { Improved handoff } \\
\text { accuracy. }\end{array}$ & $\begin{array}{l}\text { Accessibility and } \\
\text { retainability were not } \\
\text { discussed. }\end{array}$ \\
\hline [32] & $\begin{array}{c}\text { Quadratic } \\
\text { Programming } \\
\text { (QP) }\end{array}$ & $\begin{array}{l}\text { Effective estimation } \\
\text { of GSM parameters. }\end{array}$ & $\begin{array}{l}\text { It does not improve the } \\
\text { estimated parameters. }\end{array}$ \\
\hline [33] & CBR & $\begin{array}{l}\text { Minimizes } \\
\text { congestion. }\end{array}$ & $\begin{array}{c}\text { It will fail with time as } \\
\text { population is always } \\
\text { on the rise. }\end{array}$ \\
\hline [34] & FL & $\begin{array}{c}\text { Better network } \\
\text { accessibility and } \\
\text { resource } \\
\text { management. }\end{array}$ & $\begin{array}{l}\text { Poor signal quality } \\
\text { will affect the } \\
\text { performance of the } \\
\text { system. }\end{array}$ \\
\hline$[35]$ & ANN, SOM & $\begin{array}{l}\text { Better network } \\
\text { performance } \\
\text { analysis, fast and } \\
\text { efficient } \\
\text { troubleshooting }\end{array}$ & $\begin{array}{l}\text { Only spots-out but } \\
\text { does not solve network } \\
\text { problems. }\end{array}$ \\
\hline$[36]$ & $\begin{array}{l}\text { Cell-Zooming } \\
\text { algorithm }\end{array}$ & $\begin{array}{l}\text { Reduces energy } \\
\text { consumption. }\end{array}$ & $\begin{array}{l}\text { Cellular network KPIs } \\
\text { were not captured. }\end{array}$ \\
\hline [37] & MECP & $\begin{array}{l}\text { Cost reduction in } \\
\text { cellular network } \\
\text { operation. }\end{array}$ & $\begin{array}{l}\text { QoS and overall user } \\
\text { satisfaction was not } \\
\text { considered. }\end{array}$ \\
\hline [38] & Fuzzy TOPSIS & $\begin{array}{l}\text { Rise in handover } \\
\text { success rate. }\end{array}$ & $\begin{array}{l}\text { Very few quality of } \\
\text { service KPIs were } \\
\text { considered. }\end{array}$ \\
\hline
\end{tabular}

The algorithms help in visualizing and classifying similarly behaving cells. Thus, it is easier for a human expert to discern different states of the network with respect to the cells. Authors in [36] presented a proposal on cell zooming for cost-efficient green cellular networks. They introduced a concept of cell zooming, which adaptively adjusts the cell size according to traffic load, user requirements, and channel conditions. Centralized and distributed cell zooming algorithms were developed, and simulation results show that the proposed algorithms can reduce energy consumption. Authors in [28] proposed a context aware fuzzy rule based vertical handoff decision strategy for heterogeneous wireless networks. They proposed a QoS aware fuzzy rule based vertical handoff mechanism using fuzzy logic quantitative decision algorithm (FQDA) to run handoff decision criteria to choose which network to handover among different available networks. The QoS parameters considered are available bandwidth, end-to- end delay, jitter, and bit error rate (BER). Authors in [37] proposed minimizing energy cost by dynamic switching (ON/OFF) the BSs in cellular network operations. The proposed scheme uses an algorithm to solve the Minimum Energy Cost Problem (MECP) in two steps. The simulation results show that the proposed scheme can achieve significant energy cost reduction of the cellular network, but the QoS and overall user satisfaction were not considered. Authors in [38] proposed a traffic prediction based power saving in cellular networks using a machine learning method. The research exploits a machine learning method to estimate the BS traffic and proposes a BS sleeping strategy based on predicted traffic for power saving in the cellular network. Network traffic was analyzed in terms of temporal influence, spatial influence, and event influence. A multi-view learning model that predicts network traffic load, learns the traffic in multi-views and combines the results, was proposed and developed. The traffic prediction algorithm improves about $40 \%$ the state-of-the-art machine learning methods and yields about $10 \%$ more energy saving and less device damage than the competitors in the simulated environment. Table II lists the above mentioned techniques and implementations with their advantages and disadvantages.

\section{AI IN CELLULAR NETWORK OPTIMIZATION}

In a wireless cooperative cellular data network with a BS and many users in which the subscribers have the ability to relay information for each other to improve overall network performance, optimization of physical-layer transmission strategies can be done efficiently. For a wireless network operating in a frequency-selective slow-fading environment, the choices of a relay node, relay strategy, and the allocation of power and bandwidth for each user are important design parameters to be optimized [39]. For wireless cellular and ad hoc networks with QoS constraints, allocation of network resources to optimize SIR, maximize throughput and minimize delay is really necessary [40]. For small cell technology to significantly increase the capacity of tower-based cellular networks, mobile users will need to be actively pushed onto the more lightly loaded tiers (corresponding to, e.g., pico and femto-cells), even if they offer a lower instantaneous SINR than the macro-cell base station (BS). Optimizing a function of the long-term rate for each user requires (in general) a massive utility maximization problem over all the SINRs and BS loads [41]. Authors in [42] proposed an analyzing mobile radio access network using SOM. They presented a model of the network using state vectors with parameters from all mobile cells or a general one cell model trained by utilizing one cell state vector from all cells. Authors in [43] proposed cellular network optimization through automated BS placement and dimensioning for network planning. Authors in [44] proposed a system the uses fuzzy inference to improve TCP congestion control over wireless networks. The system uses environmental variables available to TCP implementations to feed a fuzzy inference system that classifies packet loss due to congestion or wireless problem without sacrificing the end-to-end reliability of TCP. Authors in [45] proposed an optimization approach that accesses network selection based on FL and GA. The research presented a general scheme to solve the access network selection (ANS) problem in a heterogeneous wireless 
network (HWN). A combination of FL and GA were used to give the proposed scheme the required scalability, flexibility, and simplicity. Authors in [46] proposed a condition monitoring of $3 \mathrm{G}$ cellular networks through competitive neural models. The proposed scheme uses frequency sensitive competitive learning, SOM and neural-gas (NG) algorithm to evaluate the overall condition of a cellular system and discover abnormal conditions. The system performs well in cellular network snag detection but fails in corrections. Authors in [47] proposed an adjustment of a fuzzy logic controller for IS-HO parameters. Performance assessment was carried out by implementing the FLC and IS-HO algorithms in a dynamic network simulator including GSM and UMTS radio access technologies. The results showed a significant reduction in blocked call rates. System flaws include accessibility, integrity, and QoS in general. Authors in [48] studied handover as a major parameter in cellular network optimization and they proposed an automatic link balancing using FL control of the handover parameter. The research presents a novel selfoptimization algorithm based on FL control. Taking into consideration measurements gathered from the network, the fuzzy logic controller balances continuously the individual link gain and the network gain. Although the system increased the capacity by $23 \%$, the QoS was negatively affected as the system only optimizes service accessibility. Authors in [49] proposed an evolvable FL system utilizing GA for handoff management in a heterogeneous wireless network. Authors in [50] proposed optimization of load balancing using fuzzy Qlearning for next-generation wireless networks. An FLC optimized by the fuzzy Q-Learning algorithm was proposed for the load balancing problem, with the aim of decreasing call blocking in congested cells, while at the same time restricting call dropping in neighbouring cells according to the network policy. Results show that the optimized FLC provides a notable reduction in call blocking while preserving call dropping under the operator constraints. The system does not improve retainability as it does to accessibility. Authors in [51] proposed adaptive neuro-fuzzy inference models for speech and video quality prediction in real-world mobile communication networks. The research optimizes speech and video quality parameters using fuzzy inference models. Table III lists the above mentioned techniques and implementations with their advantages and disadvantages.

\section{CHALlenges}

\section{A. Design}

Telecommunication operators are facing the challenge of deploying UMTS. The target of having to meet users' expectations, tight budget constraints, and governmental regulations slow network design and implementation. Careful dimensioning of the radio access infrastructure plays an essential role in achieving these targets [52]. Deployment of cellular networks involves substantial capital investment. Competition motivates service providers to minimize the cost while maintaining QoS [53]. Cell planning (CP) is the most important phase in the life cycle of a cellular system as it determines the operational expenditure (OPEX), capital expenditure (CAPEX), and the long-term performance of the system [54].
TABLE III. AI IN CELLULAR NETWORK OPTIMIZATION

\begin{tabular}{|c|c|c|c|}
\hline Reference & AI technique & Advantages & Disadvantages \\
\hline$[42]$ & SOM & $\begin{array}{l}\text { Effective data } \\
\text { handling. }\end{array}$ & $\begin{array}{l}\text { Handled data do no } \\
\text { improve network } \\
\text { performance. }\end{array}$ \\
\hline [43] & $\begin{array}{l}\text { Fuzzy Expert } \\
\text { System (FES) }\end{array}$ & $\begin{array}{l}\text { Improvement in the } \\
\text { signal coverage and } \\
\text { traffic capacity with } \\
\text { minimal } \\
\text { interference. }\end{array}$ & $\begin{array}{l}\text { Has not been tested } \\
\text { in urban areas. }\end{array}$ \\
\hline [44] & FL & $\begin{array}{c}\text { Reduces packet } \\
\text { losses caused by } \\
\text { network congestion. }\end{array}$ & $\begin{array}{l}\text { Other packet loss } \\
\text { causes were not } \\
\text { considered. }\end{array}$ \\
\hline [45] & FL and GA & $\begin{array}{l}\text { Flexible, scalable, } \\
\text { capable of reducing } \\
\text { block call rate. }\end{array}$ & $\begin{array}{l}\text { It will fail in } \\
\text { reducing dropped } \\
\text { call rate. }\end{array}$ \\
\hline [46] & SOM and NG & $\begin{array}{l}\text { Ability to detect } \\
\text { network snags. }\end{array}$ & $\begin{array}{l}\text { Unable to correct } \\
\text { the detected network } \\
\text { snags. }\end{array}$ \\
\hline [47] & FLC & $\begin{array}{c}\text { Significant } \\
\text { reduction in blocked } \\
\text { call rate. }\end{array}$ & $\begin{array}{l}\text { Network accessed } \\
\text { after an unknown } \\
\text { number of trials }\end{array}$ \\
\hline [48] & FLC & $\begin{array}{l}\text { Improved handover } \\
\text { and capacity by } 23 \%\end{array}$ & $\begin{array}{l}\text { Does not consider } \\
\text { signal quality as an } \\
\text { optimization } \\
\text { parameter }\end{array}$ \\
\hline [49] & FL and GA & $\begin{array}{l}\text { Improvements on } \\
\text { signal coverage and } \\
\text { data rates }\end{array}$ & $\begin{array}{l}\text { Signal quality and } \\
\text { data throughput } \\
\text { latency performance } \\
\text { are a major draw- } \\
\text { back }\end{array}$ \\
\hline [50] & FLC & $\begin{array}{c}\text { Reduces call } \\
\text { blocking and } \\
\text { stabilizes cell load } \\
\text { balancing }\end{array}$ & $\begin{array}{l}\text { Does not impact on } \\
\text { dropped call rate } \\
\text { and radio } \\
\text { environment }\end{array}$ \\
\hline [51] & Neuro-Fuzzy & $\begin{array}{c}\text { Estimates and } \\
\text { predicts speech and } \\
\text { video quality }\end{array}$ & $\begin{array}{c}\text { Does not improve } \\
\text { network signal } \\
\text { quality }\end{array}$ \\
\hline
\end{tabular}

\section{B. Operation}

With the ever-growing demand of data applications, traditional cellular networks face the challenge of providing enhanced system capacity, extended cell coverage, and improved minimum throughput in a cost-effective manner. Wireless relay stations, especially when operating in halfduplex operation, make it possible without incurring high site acquisition and backhaul costs. Design of wireless relay stations faces the challenges of providing backward compatibility, minimizing complexity, and maximizing efficiency [55]. Mobile communications are increasingly contributing to global energy consumption. At the network level, the potential for reducing energy consumption is in the layout of networks and their management, that take into account slowly changing daily load patterns, and highly dynamic traffic fluctuations [56]. The operation of cellular network infrastructure incurs significant electrical energy consumption. Reducing this consumption is not only a matter of showing environmental responsibility but also of substantially reducing operational expenditures [57]. The operation of mobile networks is a complex task with the networks serving a large number of users with voice and data services, containing extensive sets of elements, generating extensive amounts of measurement data and being controlled by a large number of parameters. A major objective is to ease 
the operation of mobile networks by introducing advanced monitoring and automated optimization methods [58].

\section{Optimization}

In cellular network optimization, coverage and capacity planning remain the major challenges and should be addressed simultaneously [59]. Optimization is necessary for cellular network activities as it will trigger maximum efficiency. Network snags such as blocked or dropped calls, poor signal coverage and quality, and insufficient bandwidth force the devices to reduce the audio bandwidth or even ban access, or slow down response times for data downloading, continue to make network optimization inevitable.

\section{FUTURE WORK}

Designing a cellular network that uses an AI system that intelligently sorts and uses hopping sequence numbers and broadcasts control channel re-assignment will reduce blocked and dropped calls and will improve QoS. The system should also be able to reduce cell transmit power and promote optimal cell utility. This is very essential as the $4 \mathrm{G}$ network falls back to GSM/UMT network during circuit switch services.

\section{CONCLUSION}

Application of AI in cellular network design, operation, and optimization aims at improving QoS in a cellular network. The increase in the number of mobile users and the overwhelming demand of offered services by the network providers affect the network QoS and a high demand for optimization emerges. Engineers need to ensure that key performance benchmarks are met. In this paper, an extensive review of the current AI applications has been performed and their advantages, disadvantages, challenges, and future scopes were presented. Deploying AI in the telecommunications field improves the overall QoS. Improvements have been noticed in Key Performance Indicators (KPIs) such as blocked call rate, dropped call rate, handover success rate, signal coverage and quality, latency and data throughput, but on individual KPI bases. To telecommunication operators and users, the system to be deployed should be cost-effective and possess primary capabilities to access the network and retain network services. As such, the expert system and AI agents should be costeffective and improve network service accessibility and retainability. New research should be focused on these areas:

- Designing a cost-effective communication paradigm that is AI driven in network design, operation, and management.

- Designing an AI system that uses hopping sequence number and broadcast control channel re-assignment to reduce blocked and dropped calls, and improve QoS.

\section{REFERENCES}

[1] S. Singh, P. Kumar, "Challenges and prospects of wireless network in 4G”, International Journal of Computer Applications, Vol. 133, No. 11, pp. 1-5, 2016

[2] D. Banupriya, Pandi, S. Preetha, R. R. Prathisha, "A study on use of artificial intelligence in wireless communications", Asian Journal of Applied Science and Technology, Vol. 2, No. 1, pp. 354-360, 2018

[3] S. J. Russell, P. Norvig, Artificial Intelligence: A Modern Approach, Prentice Hall, 2009
[4] G. Luger, W. Stubblefield, Artificial Intelligence: Structures and Strategies for Complex Problem Solving, Addison Wesley, 1993

[5] R. J. Schalkoff, Artificial Intelligence: An Engineering Approach, McGraw-Hill, 1990

[6] Ministry of Internal Affairs and Communications, "Present and Future of Artificial Intelligence (AI)", in: White Paper on Information and Communications in Japan, MIC, 2016

[7] T. Otani, H. Toube, T. Kimura, M. Furutani, "Application of AI to mobile network operation”, ITU Journal: ICT Discoveries, Special Issue No. 1, pp. 1-7, 2017

[8] S. Shakkottai, T. S. Rappaport, P. Karlsson, "Cross-layer design for wireless network", IEEE Communications Magazine, Vol. 41, No. 10, pp. 74-80, 2003

[9] A. Ganz, D. Tang, C. M. Krishna, Z. J. Haas, "On optimal design of multitier wirelee cellular systems", IEEE Communications Magazine, Vol. 35, No. 2, pp. 88-93, 1997

[10] A. Snow, P. Rastogi, G. Weckman, "Assessing Dependability of Wireless Networks Using Neural Networks", 2005 IEEE Military Communications Conference, Atlantic City, USA, October 17-20, 2006

[11] H. Dubreil, V. Diascorn, Z. Altman, J. M. Picard, "Particle Swarm Optimization of Fuzzy Logic Controller for High Quality RRM AutoTuning of UMTS Networks", IEEE 61st Vehicular Technology Conference, Stokholm, Sweden, May 30-June 1, 2005

[12] X. Fu, W. Zhou, J. Xu, J. Song, "Extended Mobility Management Challenges Over Cellular Networks Combined with Cognitive Radio by Using Multi-hop Network", 8th ACIS International Conference on Software Engineering, Artificial Intelligence, Networking and Parallel/Distributed Computing, Qingdao, China, July 30-August 1, 2007

[13] C. Werner, S. Khattak, J. Voigt, G. Fettweis, "Handover Parameter Optimization in WCDMA using Fuzzy Controlling", 18th International Symposium on Personal, Indoor and Mobile Radio Communications, Athens, Greece, September 3-7, 2007

[14] Y. H. Chen, C. J. Chang, C. Y. Huang, "Fuzzy q-learning admission control for WCDMA/WLAN heterogeneous networks with multimedia traffic", IEEE Transactions on Mobile Computing, Vol. 8, No. 11, pp. 1469-1479, 2009

[15] L. M. Tirado, J. E. S. Pietri, J. H. Reed, “A Hybrid Cognitive Engine for Improving Coverage in 3G Wireless Networks", IEEE International Conference on Communications Workshops, Dresden, Germany, June 14-18, 2009

[16] X. Yan, Y. A. Sekercioglu, S. Narayanan, "A survey of vertical handover decision algorithms in fourth generation heterogeneous wireless networks", Computer Networks, Vol. 54, No. 11, pp. 18481863,2010

[17] A. Tudzarovl, T. Janevski, "Efficient radio access technology selection for the next generation wireless networks", International Journal of Research and Reviews in Next Generation Networks, Vol. 1, No. 1, pp. 14-25, 2011

[18] A. Calhan, C. Ceken, Artificial Neural Network Based Vertical Handoff Algorithm for Reducing Handoff Latency, Springer, 2013

[19] L. Barolli, M. Durresi, K. Sugita, A. Durresi, A. Koyama, "A CAC Scheme for Multimedia Applications Based on Fuzzy Logic", 19th International Conference on Advanced Information Networking and Applications, Taipei, Taiwan, March 28-30, 2005

[20] P. M. Papazoglou, D. A. Karras, R. C. Papademetriou, "Improved integral channel allocation algorithms in cellular communication systems enabling multimedia QoS services", WSEAS Transactions on Communications, Vol. 7, No. 10, pp. 1014-1023, 2008

[21] S. Chantaraskul, L. Cuthbert, "An intelligent-agent approach for congestion management in $3 \mathrm{G}$ networks", Engineering Applications of Artificial Intelligence, Vol. 21, No. 4, pp. 619-632, 2008

[22] F. Fan, X. Li, "The Application of Fuzzy Reasoning in Communication Network Fault Diagnosis", IEEE International Conference on Control Science and Systems Engineering, Yantai, China, December 29-30, 2014 
[23] S. H. Alsamhi, N. S. Rajput, "An intelligent hand-off algorithm to ehance quality of service in high altitude platforms using neural network", IEEE Transactions on Wireless Communications, Vol. 82, No. 4, pp. 2059-2073, 2015

[24] T. Inaba, D. Elmazi, S. Sakamoto, T. Oda, M. Ikeda, L. Barolli, “A secure-aware call admission control scheme for wireless cellular networks using fuzzy logic and its performance evaluation”, Journal of Mobile Multimedia, Vol. 11, No. 3-4, pp. 213-222, 2015

[25] T. Sigwele, P. Pillai, Y. F. Hu, "Elastic call admission control using fuzzy logic in virtualized cloud radio base stations", Wireless and Satellite Systems, Vol. 154, pp. 359-372, 2015

[26] M. R. Reghita, V. Paul, S. Sivan, N. Antony, "Handoff delay optimization using hybrid prediction model", International Journal of Networked and Distributed Computing, Vol. 6, No. 2, pp. 99-107, 2018

[27] C. Peng, S. B. Lee, S. Lu, H. Li, H. Luo, "Traffic-Driven Power Saving in Operational 3G Cellular Networks", 17th Annual International Conference on Mobile Computing and Networking, Las Vegas, USA, September 19-23, 2003

[28] M. S. Kausar, D. Cheelu, "Context aware fuzzy rule based vertical handoff decision strategies for heterogeneous wireless networks", International Journal of Engineering and Science, Vol. 3, No. 7, pp. 612,2013

[29] P. M. L. Chan, R. E. Sheriff, Y. F. Hu, P. Conforto, C. Tocci, "Mobility management incorporating fuzzy logic for a heterogeneous IP environment", IEEE Communications Magazine, Vol. 39, No. 12, pp. 42-51, 2001

[30] Z. Salcic, "GSM mobile station location using reference stations and artificial neural networks", Wireless Personal Communications, Vol. 19, No. 3, pp. 205-226, 2001

[31] Q. Guo, J. Zhu, X. Xu, "An Adaptive Multi-Criteria Vertical Handoff Decision Algorithm for Radio Heterogeneous Network", IEEE International Conference on Communications, Seoul, South Korea, May 16-20, 2005

[32] P. Lehtimaki, K. Raivio, "A Knowledge-Based Model for Analyzing GSM Network Performance", 6th International Symposium on Intelligent Data Analysis, Madrid, Spain, September 8-10, 2005

[33] N. Yao, L. Cuthbert, "Resource Management in 3G Networks Using Case-Based Reasoning", 8th ACM International Symposium on Modelling, Analysis and Simulation of Wireless and Mobile Systems, Montreal, Canada, October 10-13, 2005

[34] S. Malarkkanl, V. C. Ravichandran, "Performance analysis of call admission control in WCDMA system with adaptive multi class traffic based on fuzzy logic", International Journal of Computer Science and Network Security, Vol. 6, No. 11, pp. 215-222, 2006

[35] J. Laiho, K. Raivio, P. Lehtimaki, K. Hatonen, O. Simula, "Advanced analysis methods for $3 \mathrm{G}$ cellular networks", IEEE Transactions on Wireless Communications, Vol. 4, No. 3, pp. 930-942, 2007

[36] Z. Niu, Y. Wu, J. Gong, Z. Yang, "Cell zooming for cost-efficient green cellular networks", IEEE Communications Magazine, Vol. 49, No. 11, pp. 74-79, 2010

[37] N. Yu, Y. Miao, L. Mu, H. Du, H. Huang, X. Jia, "Minimizing energy cost by dynamic switching ON/OFF base stations in cellular networks", IEEE Transactions on Wireless Communications, Vol. 15, No. 11, pp. 7457-7469, 2016

[38] S. Zhang, S. Zhao, M. Yuan, J. Zeng, J. Yao, M. R. Lyu, I. King, "Traffic Prediction Based Power Saving in Cellular Networks: A Machine Learning Method", 25th ACM SIGSPATIAL International Confeerence on Advances in Geographical Information Systems, Redondo Beach, USA, November 7-10, 2017

[39] T. C. Y. Ng, W. Yu, "Joint optimization of relay strategies and resource allocations in cooperative cellular networks", IEEE Journal on Selected Areas in Communications, Vol. 25, No. 2, pp. 328-339, 2007

[40] D. Julian, M. Chaing, D. O’Neil, S. Boyd, "QoS and Fairness Constrained Convex Optimization of Resource Allocation for Wireless Cellular and Ad Hoc Networks", 21st Annual Joint Conference of the IEEE Computer and Communications Societies, New York, USA, June $23-27,2002$
[41] Q. Ye, B. Rong, Y. Chen, M. A. Shalash, C. Caramanis, J. G. Andrews, "User association for load balancing in heterogeneous cellular networks", IEEE Transactions on Wireless Communications, Vol. 12, No. 6, pp. 2706-2716, 2013

[42] K. Raivio, O. Simula, J. Laiho, P. Lehtimaki, “Analysis of Mobile Radio Access Network Using the Self-Organizing Map", 8th International Symposium on Integrated Network Management, Colorado Springs, USA, March 24-28, 2003

[43] X. Huang, U. Behr, W. Wiesbeck, "Automatic Base Station Placement and Dimensioning for Mobile Network Planning", 52nd Vehicular Tchnology Conference, Boston, USA, March 24-28, 2003

[44] H. Aarag, M. Wozniak, "Using Fuzzy Inference to Improve TCP Congestion Control over Wireless Networks", 15th Communication and Networking Simulation Symposium, Florida, USA, March 26-30, 2012

[45] A. Ayesh, M. Alkhawlani, "Access Network Selection Based on Fuzzy Logic and Genetic Algorithms", Association for Computing Machinery, Vol. 2008, Article ID 793058, 2008

[46] G. A. Barreto, J. C. M. Mota, L. G. M. Souza, R. A. Frota, L. Aguayo, "Condition monitoring of $3 \mathrm{G}$ cellular networks through competitive neural models", IEEE Transactions on Neural Networks, Vol. 16, No. 5, pp. 1064-1075, 2005

[47] S. L. Ramorez, M. Toril, F. Ruiz, M. F. Navarro, "Adjustment of a Fuzzy Logic Controller for IS-HO Parameters in a Heterogeneous Scenario", 14th IEEE Mediterranean Electrotechnical Conference, Ajaccio, France, May 5-7, 2008

[48] P. M. d'Orey, M. G. Luzano, M. Ferreira, “Automatic Link Balancing using Fuzzy Logic Control of Handover Parameter", 21st Annual IEEE International Symposium on Personal, Indoor and Mobile Radio Communications, Istanbul, Turkey, September 26-30, 2010

[49] H. Fayyazi, M. Sabokrou, "An Evolvable Fuzzy Logic System for Handoff Management in Heterogeneous Wireless Networks", 2nd International Conference on Computer and Knowledge Engineering, Mashland, Iran, October 18-19, 2012

[50] P. Munoz, R. Barco, I. D. L. B. Cascales, "Optimization of load balancing using fuzzy q-learning for next generation wireless networks", Expert Systems with Applications, Vol. 40, No. 4, pp. 984-994, 2013

[51] C. N. Pitas, D. E. Charilas, A. D. Panagopoulos, P. Constantinou, "Adaptive neuro-fuzzy inference models for speech and video quality prediction in real-world mobile communication networks", IEEE Wireless Communications, Vol. 20, No. 3, pp. 80-88, 2013

[52] A. Eisenblatter, R. Wessaly, A. Martin, A. Fugenschuh, O. Wegel, T. Koch, T. Achterberg, A. Koster, Modelling Feasible Network Configurations for UMTS, Springer, 2003

[53] A. Dutta, V. Hsu, "Cellular network design site selection and frequency planning", Annals of Operations Research, Vol. 106, No. 1-4, pp. 287306, 2001

[54] A. Taufique, M. Jaber, A. Imran, Z. Dawy, E. Yacoub, "Planning wireless cellular networks of future: Outlook, challenges and opportunities", IEEE Access, Vol. 5, pp. 4821-4845, 2017

[55] C. Hoymann, W. Chen, J. Montojo, A. Golitschek, C. Koutsimanis, X. Shen, "Relaying operation in 3GPP LTE: Challenges and solutions", IEEE Communications Magazine, Vol. 50, No. 2, pp. 156-162, 2012

[56] L. M. Correia, D. Zeller, O. Blume, D. Ferling, Y. Jading, I. Godor, G. Auer, L. V. D. Perre, "Challenges and enabling technologies for energy aware mobile radio networks", IEEE Communications Magazine, Vol. 48, No. 11, pp. 66-72, 2010

[57] E. Oh, B. Krishnamachar, X. Liu, Z. Niu, "Toward dynamic energyefficient operation of cellular network infrastructure", IEEE Communications Magazine, Vol. 49, No. 6, pp. 56-61, 2011

[58] A. Hoglund, Advanced Mobile Network Monitoring and Automated Optimization Methods, Helsinki University of Technology, 2006

[59] E. Amaldi, A. Capone, F. Malucelli, C. Mannino, Optimization Problems and Models for Planning Cellular Networks, Springer, 2014 